\title{
The Little Blue Heron in Saskatchewa
}

\author{
By Dr. STUART HOUSTON, Yorkton
}

Joyce Gunn reported four Little Blue Herons at Good Spirit Lake, northwest of Yorkton, on May 24, 1956. This constituted the first sight record of this species for Saskatchewan. (BLUE JAY, XIV, Sept. 1956, p. 90$)$.

On Sept. 9, 1956, Mr. and Mrs. W. J. McDonald and Betty McDonald of Yorkton reported a white bird resembling an egret, wading in the marsh just east of Number 9 Highway at Crescent Lake, about 16 miles south of Yorkton. They noted it again on Sept. 14, when it was also seen by Cliff Shaw of Yorkton and B. W. Cartwright, chief Naturalist of Ducks Unlimited. On Sept. 15, it was seen by Mary Houston. On Sept 16, Stuart and Mary Houston watched it for a total of five hours, and good views were obtained with $7 x$ and $10 x$ binoculars at 20 yards and with a $40 \mathrm{x}$ telescope at greater distances. Several photographs were taken with a borrowed telephoto lens.

The bird was definitely smaller than the bitterns which would land beside it. The feet and legs were a greyish green. There was no yellow on the toes. The bill was bluish grey and black at the tip. The plumage was uniformly white, with no bluish cr buff. This could only be the juvenile plumage of the Little Blue Heron. Dr. R. W. Nero of the Saskatchewan
Museum of Natural History phoned, and he came up and obs ed the bird but did not collect i was ther absent until Sept. 19, w it was again reported by the Donalds. On Sept. 20 it was aई seen by the Houstons. It was seen on Sept. 21 by Mary Hous

Pough, in the AUDUBON B. GUIDE, states: "In inland fre water marshes of the South the L Blue is generally the commo: heron... After the breeding sea it wanders north in greater num than any other southern heron ex the egret. Most individuals ence tered in the North are the pi white young of the year; as a re they are often mistaken for es or snowy egrets."

These exotic southern birds a welcome addition to the Saskat wan bird list. Saskatchewan watchers should be on the lool for the American Egret, Snowy E and Little Blue Heron. If the $t r$ continues, who knows but that Green Heron and Cattle Egret yet be seen within our borders?

EDITOR'S NOTE: The President has $p$ on to us an observation from Mr. McLellan, Arcola, dated Aug. 10, 1956. McLellan's note reads, "A pair of Little Herons (Florida caerulea) are nesting but I have not found the nest. I am ilc there is a group of 20 or more abou 20 miles north of Kisbey. They have not re viously been seen here."

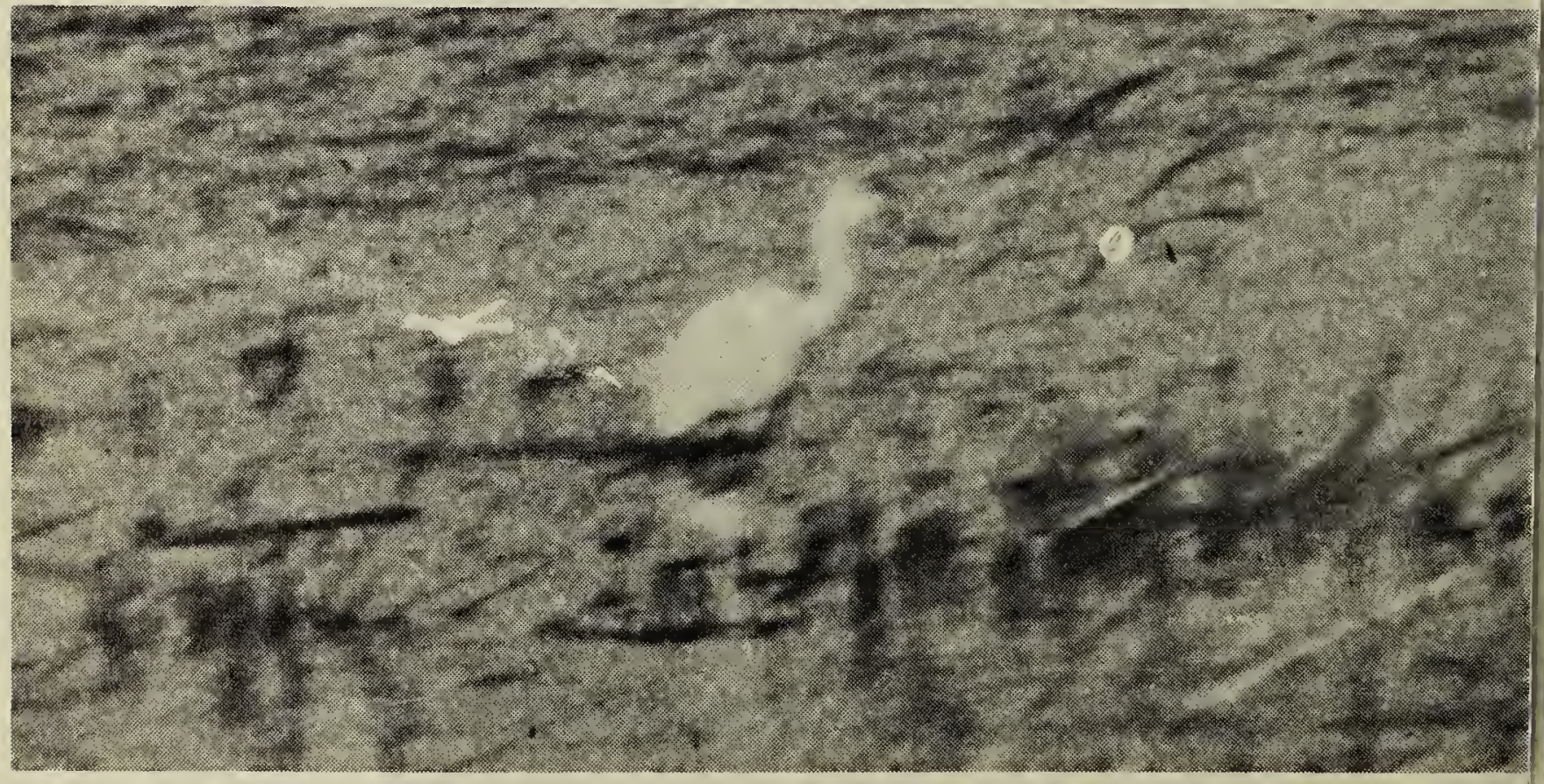

Kodachrome! telephoto by Dr. S. Hc IMMATURE LITTLE BLUE HERON 